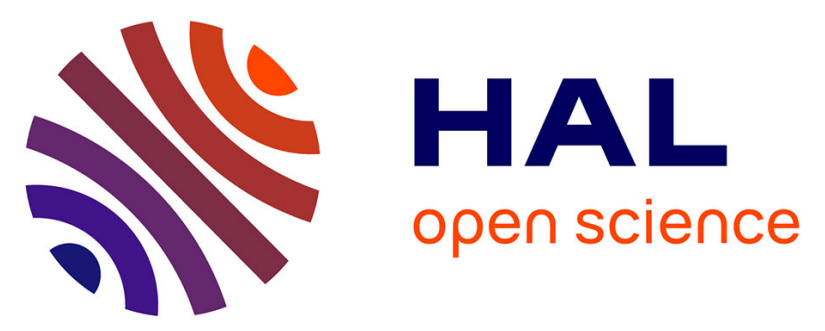

\title{
Current ways to modify the structure of whey proteins for specific functionalities-a review
}

Fanny Guyomarc'H, Marie-Hélène Famelart, Gwenaele Henry, Muhammad Gulzar, Joelle Léonil, Pascaline Hamon, Said Bouhallab, Thomas Croguennec

\section{- To cite this version:}

Fanny Guyomarc'H, Marie-Hélène Famelart, Gwenaele Henry, Muhammad Gulzar, Joelle Léonil, et al. Current ways to modify the structure of whey proteins for specific functionalities-a review. Dairy Science \& Technology, 2015, 95 (6), 10.1007/s13594-014-0190-5 . hal-01209713

\section{HAL Id: hal-01209713 \\ https://hal.science/hal-01209713}

Submitted on 27 May 2020

HAL is a multi-disciplinary open access archive for the deposit and dissemination of scientific research documents, whether they are published or not. The documents may come from teaching and research institutions in France or abroad, or from public or private research centers.
L'archive ouverte pluridisciplinaire HAL, est destinée au dépôt et à la diffusion de documents scientifiques de niveau recherche, publiés ou non, émanant des établissements d'enseignement et de recherche français ou étrangers, des laboratoires publics ou privés. 


\title{
Current ways to modify the structure of whey proteins for specific functionalities-a review
}

\author{
Fanny Guyomarc'h • Marie-Hélène Famelart • \\ Gwénaële Henry • Muhammed Gulzar • \\ Joëlle Leonil • Pascaline Hamon • Saïd Bouhallab • \\ Thomas Croguennec
}

Received: 3 June 2014 / Revised: 9 July 2014 / Accepted: 24 July 2014

C INRA and Springer-Verlag France 2014

\begin{abstract}
The native whey proteins have been intensively used in a multitude of food applications due to their high nutritional, biological, and versatile technofunctional properties. The range of applications of whey proteins has further been extended in the last decades by the use of whey protein aggregates offering new technofunctional properties. These properties are directly dependent on the structure of whey protein aggregates, i.e., their size, shape, density, surface properties, and the type of bonds maintaining proteins together in the aggregates. In this review, after a brief description of the major whey proteins, we examine the most important advances reported to date pertaining to the available approaches to modify the structure of whey proteins for specific functionalities. Our laboratory, Science and Technology of Milk and Eggs, has contributed significantly to the advancement of knowledge on the structure-function relationships of whey proteins either in the native or denatured/aggregated forms. Our expertise and research approaches are highlighted throughout some selected results accumulated during the last decade in comparison with results from the literature.
\end{abstract}

Keywords Whey proteins $\cdot$ Structure $\cdot$ Functionalities $\cdot$ Assemblies

\section{Introduction}

Milk proteins are classified into two groups (caseins and whey proteins) based on their solubility at pH 4.6 after acidification of a raw skim milk (Farrell et al. 2004). Milk

This paper is part of the special issue dedicated to the 10th anniversary of the INRA-Agrocampus Ouest joint research unit.

F. Guyomarc'h • M.-H. Famelart • G. Henry • M. Gulzar • J. Leonil • P. Hamon • S. Bouhallab •

T. Croguennec

INRA, UMR1253 STLO, 65 rue de Saint Brieuc, 35042 Rennes, France

F. Guyomarc'h • M.-H. Famelart • G. Henry • M. Gulzar • J. Leonil • P. Hamon • S. Bouhallab •

T. Croguennec $(\bowtie)$

AGROCAMPUS OUEST, UMR1253 STLO, 65 rue de Saint Brieuc, 35042 Rennes, France

e-mail: thomas.croguennec@agrocampus-ouest.fr 
proteins in their native form exert highly valuable properties giving them incomparable assets in numerous food applications. In terms of nutrition, milk proteins have wellbalanced amino acid composition and the amino acid sequence in the polypeptide chains forms various types of bioactive peptides that are discretely released upon protein hydrolysis (Korhonen and Pihlanto 2006). They are carriers of micronutrients (minerals and vitamins) and fatty acids, and exhibit some health benefit activities including antimicrobial, antiviral, anticancer, and modulation of immune system. Milk proteins are also appreciated in food formulation for their dispersibility, solubility, and stability towards processing, their ability to form different types of gels, to stabilize emulsions and foams, their appearance, taste, and flavor. These properties allow the building of the large diversity of textures of dairy products and many other food products. In spite of their excellent functional properties, dairy product manufacturers sometimes replace part of milk proteins by other ingredients or additives in order to reduce the cost, improve stability, and extend the diversification of dairy product texture. These replacements grey over the image of naturality conveyed by dairy products, a recent food quality concern expressed by the clean-label tendency. On a wider scale, it questions the way foodstuff is produced integrating traceability consideration, eco-conception approach, reflection about the use of ingredients or additives for healthier, more natural and environmental-friendly foods, without renouncing to other traditional food product quality criteria (security, practicability, pleasure, etc.). Research in the past decades has proven that whey proteins are highly versatile allowing their extensive modifications and assemblies in order to create unexpected new structures (nanotubes, fibers, spheres, etc.). The functionalities of these new structures in real food systems are not completely understood or even tested but this opens the door to putative new possibilities of using milk protein ingredients for extending their functional applications. They could allow the reformulation of food products matching better with consumer's expectations in term of nutrition, texture, taste, naturalness, durability, etc., and the advent of products echoing new usages and new consumption habits. In this review, we report on the most recent advances on the controlled modifications of whey protein structures for specific functionalities with a large focus on the research ongoing in our laboratory.

\section{Whey proteins}

\subsection{Native whey proteins}

Whey proteins describe the group of milk proteins that remain soluble after casein (CN) precipitation at $\mathrm{pH}$ 4.6. In this section, a brief overview of the structural characteristics of the main milk globular proteins is presented.

\subsection{1 $\beta$-Lactoglobulin}

$\beta$-Lactoglobulin $(\beta$-LG) is the major whey protein in bovine milk. Several genetic variants of $\beta$-LG exist, $A$ and $B$ being the most common, which only differ by two amino acids at positions 64 and 118; acid aspartic at position 64 and valine at position 118 of variant A are replaced in variant B by glycine and alanine, respectively. Hence, 
each variant has 162 amino acids with a molecular weight $(\mathrm{Mw})$ of around $18.3 \mathrm{kDa}$. $\beta$-LG molecular structure is well-established (Brownlow et al. 1997): basically, $\beta$-LG has $15 \% \alpha$-helix, $50 \% \beta$-sheet, and $15-20 \%$ reverse turn. The $\beta$-strands (labeled A to I) are organized into two $\beta$-sheets facing each other and forming a flattened and conical barrel, called a calyx, as determined by X-ray crystallography (PAPIZ et al. 1986). This calyx constitutes an ideal binding site for hydrophobic ligands (Brownlow et al. 1997; Sawyer and Kontopidis 2000; Kontopidis et al. 2002; Le Maux et al. 2014). $\beta$-LG has 5 cysteins, 4 of which forming 2 disulfide bonds. The remaining free thiol group is buried within the protein structure on the $\beta$-strand $H$. The disulfide bonds contribute to the reversible denaturation of $\beta$-LG (Kitabatake et al. 2001), whereas the free thiol stabilizes the native protein structure (Jayat et al. 2004). At room temperature, $\beta$-LG exhibits $\mathrm{pH}$-dependent reversible self-association behavior (Yan et al. 2013). At neutral $\mathrm{pH}(5.5-7.5)$, a stable noncovalent dimer is formed, whereas around its $p I$ (5.2), $\beta$-LG exists as octamer. At $\mathrm{pH}$ below 3.5 and above $7.5, \beta-\mathrm{Lg}$ is mainly monomer. Oligomeric state of $\beta-\mathrm{LG}$ is also sensitive to ionic strength, temperature, and the presence of hydrophobic ligands in the central cavity of the protein. Changes in $\beta$ LG structure upon temperature increase are reviewed in Qi et al. (1997) and De Wit (2009).

\subsection{2 $\alpha$-Lactalbumin}

$\alpha$-Lactalbumin ( $\alpha$-LA) is a $\alpha+\beta$ protein with a $\alpha$-domain formed by four $\alpha$-helix and a $\beta$-domain containing one anti-parallel $\beta$-sheet of three $\beta$-strands and a flexible loop. The overall structure is weakly organized with approximately $60 \%$ of unordered structure for $25-30 \%$ of $\alpha$-helix and $10-15 \%$ of $\beta$-structure. The polypeptide chain has 123 amino acids for a Mw of $14.2 \mathrm{kDa}$ and a $p I$ between 4.2 and 4.5. $\alpha$-LA has four disulfide bonds and one site of high affinity for calcium $\left(K_{\mathrm{D}}=2.9 \times 10^{8} \mathrm{M}^{-1}\right.$; Hendrix et al. 2000) localized in the loop connecting the $\alpha$ and $\beta$ domains. $K_{\mathrm{D}}$ varies when $\mathrm{pH}$ and temperature change. Below $\mathrm{pH} 5$, the ability of $\alpha$-LA to bind calcium decreases. Calcium stabilizes $\alpha$-LA structure against heatdenaturation and accelerates its refolding (Forge et al. 1999). In the presence of calcium, the denaturation temperature of holo $\alpha$-LA is $64{ }^{\circ} \mathrm{C}$ versus around $30{ }^{\circ} \mathrm{C}$ (Bernal and Jelen 1984; Griko and Remeta 1999) for the apo-form (calcium-free $\alpha$ LA). At acidic $\mathrm{pH}$, apo $\alpha$-LA adopts a molten globule conformation. Under this conformation, apo $\alpha$-LA forms microscopic aggregates when temperature increases beyond $50{ }^{\circ} \mathrm{C}$.

\subsubsection{Bovine serum albumin}

Bovine serum albumin (BSA) is a helical protein (56-83\% $\alpha$-helix) with a molar mass of $66.4 \mathrm{kDa}$ and a $\mathrm{pI}$ of 4.9 (Mattison et al. 1998). Among the 582 amino acids of the polypeptide chain, 35 are cysteine forming 17 intramolecular disulfide bonds and leaving 1 thiol group at position 34 . These disulfide bonds involve only cysteine close to each others in the polypeptide chain, which is therefore organized in a series of short loops. BSA binds hydrophobic ligands such as fatty acids up to 4.5 fatty acids per BSA (Perez et al. 1989). At low ionic strength, BSA molecules self-assemble into small aggregates. 


\subsubsection{Lactoferrin}

Lactoferrin (LF) is an iron-binding glycoprotein belonging to the transferrin family. The polypeptide chain is composed of 689 amino acids (Mw of $80 \mathrm{kDa}$ ) folded in two homologous lobes (N- and C-lobes) (Moore et al. 1997). Each lobe has two domains $\left(\mathrm{N}_{1}, \mathrm{~N}_{2}\right.$ and $\left.\mathrm{C}_{1}, \mathrm{C}_{2}\right)$ forming a cleft in between that is the binding site for one iron ion (Baker and Baker 2009). Iron increases the heat stability of LF and reduces its flexibility. LF is the main basic protein in milk ( $p I$ of 8.6-8.9). However, the charge distribution on LF surface is highly uneven (Baker and Baker 2009) and evolves according to the aggregation state of LF. Indeed, LF exists as ionic strengthdependent monomer-aggregate equilibrium (Chaufer et al. 2000; Mela et al. 2010). The equilibrium is shifted to the monomer at low ionic strength (and neutral pH); under this condition, LF molecules are positively charged. At higher ionic strength, LF forms small aggregates that are neutral (Chaufer et al. 2000) or negatively charged ( $p I \sim 6)$ (Mela et al. 2010).

\subsection{Structural characteristics of whey protein assemblies and related functionalities}

While they are stable in native milk, the whey proteins are known to denature and assemble into aggregates upon heating at temperatures of $\sim 60{ }^{\circ} \mathrm{C}$ or above in milk system (Dannenberg and Kessler 1988a). The aggregates are mainly formed through thiol-disulfide interactions and other noncovalent interactions (Donato and Guyomarc'h 2009; Morand et al. 2011b). The reaction can also be achieved at lower temperatures in concentrated systems, e.g., at $35{ }^{\circ} \mathrm{C}$ in $\sim 500$ g.kg rehydrated whey protein isolate (Zhou et al. 2008). In dairy technology, the reaction adversely affects the secondary phase of renneting during cheese manufacture because the whey protein aggregates interact with the casein micelles and prevent the fusion of the rennet gel (Guyomarc'h 2006; Anema et al. 2007). On the other hand, the presence of heataggregated whey proteins is desirable in yoghurt-making, where they have long been associated with a firmer, finer, and moisturized protein gel (Dannenberg and Kessler $1988 \mathrm{~b}, \mathrm{c})$. Only $10 \% \mathrm{w} / \mathrm{w}$ of the total protein in the form of aggregated whey proteins, corresponding to about equimolar aggregates and casein micelles and to about $8 \%$ coverage of the surface of the casein micelle, suffices to significantly increase the final elasticity of acid milk gels (Andoyo et al. 2014).

Whey proteins are also reported to form a wide range of assemblies (fibrils, multistranded ribbons, spherulites, spherical particles, flexible strands, or fractals aggregates) depending on the conditions applied on heating (Nicolai and Durand 2013). Interesting perspectives are also presented by "switchable" particles of whey proteins, formed by coacervation of electrostatic-associated proteins that are reversible upon changes in the ionic environment and/or charge of the proteins (Bouhallab and Croguennec 2014). The versatility and the design of controlled structures from whey proteins essentially depend on the ability to tune the dimensions of the whey protein assemblies (shape and size), their internal arrangement (density and type of interaction involved), and the properties of the surface (surface charge and hydrophobicity). These structures offer applications in the control of food properties such as in the generation and stabilization of foams and emulsions, their use as thickening agents, or their use in the cold gelation, in the design of edible carriers for hydrophobic molecules like drugs, 
oils, or for bacteria, in the generation of edible films, and coating for controlling mass transfer between media (Nicolai et al. 2011; Tavares et al. 2014).

\subsubsection{Form factor, size, and density}

Under diluted conditions, long-range electrostatic repulsions prevent whey proteins from aggregation. This steady state may be altered upon heating the solution above whey protein denaturation temperature. As a consequence, the polypeptide chains become more mobile and reactive amino acids (hydrophobic amino acids and cysteine) initially buried in the core of the protein structure become exposed on the surface and participate to protein-protein interactions. Protein concentration, time and temperature of heating, $\mathrm{pH}$, and the presence of specific ions are the main factors affecting the dimensions of the assemblies. Some results briefly presented below on the dimensions of heat-induced assemblies of whey proteins were mainly obtained on studies conducted on $\beta$-LG and are extensively detailed in recent reviews (Nicolai et al. 2011; Nicolai and Durand 2013; Bouhallab and Croguennec 2014).

At low $\mathrm{pH}(\mathrm{pH}<2.5)$ and low ionic strength, conditions for which the protein net charge is high, whey proteins form fibrils when the solutions are heated at $80^{\circ} \mathrm{C}$ and above for several hours (Fig. 1). Fibrils are long linear aggregates inside which the polypeptides establish mainly intermolecular $\beta$-sheets that are perpendicular to the long axis of the fibrils. The kinetics of fibril formation is slow and follows a nucleation/ growth mechanism (Arnaudov and de Vries 2007). It is pointed out that a lag time during which proteins undergo some cleavages in the polypeptide backbone is required before fibril formation (Bolder et al. 2007; Akkermans et al. 2008). Under particular conditions, the fibrils of $\beta$-LG are also able to organize into larger structures such as helical ribbons (Lara et al. 2011) or spherulites (Domike and Donald 2007) (Fig. 1). Helical ribbons consist of lateral assemblies of fibrils whereas spherulites result from their radial assembly. Due to their symmetry, the spherulites exhibit a Maltese cross pattern when observed under polarizing light microscope. In the presence of salts, the spherulites grow larger and the inner core of the spherulite progressively loses its birefringence, probably because of distortion at the nucleation point of the fibrils (Domike et al. 2009).

In narrow ranges of $\mathrm{pH}(4.5-4.7$ and 5.7-5.9) on either side of whey protein $p I$ and at low ionic strength, stable suspensions of monodispersed spherical particles of about $200 \mu \mathrm{m}$ are obtained on heating (Schmitt et al. 2009) (Fig. 1). Between these two pH ranges, the spherical particles associate into large aggregates leading to a macroscopic phase separation or precipitate on aging. The same trend is observed at the $\mathrm{pH}$ of formation of the spherical particles when salt content of whey protein solutions is increased (Donato et al. 2009). More recently, it was observed that similar spherical particles of $\beta$-LG could be obtained at higher $\mathrm{pH}$ (up to $\mathrm{pH} 7.5$ ) by a careful control of the $\mathrm{Ca}^{2+} / \beta$-LG molar ratio, suggesting that the net charge of the native proteins (tunable by $\mathrm{pH}$ and $\mathrm{Ca}^{2+}$ content) is the crucial parameter for the formation of spherical particles (Phan-Xuan et al. 2014).

Small flexible strands with length of about 50-150 nm and diameter of about 5$10 \mathrm{~nm}$ are formed at low protein concentration and for $\mathrm{pH}$ conditions around 2.5-4.0 and >6.3 (Mudgal et al. 2009; Kavanagh et al. 2000). Randomly branched (fractal) aggregates resulting from the secondary aggregation of these small flexible strands are 


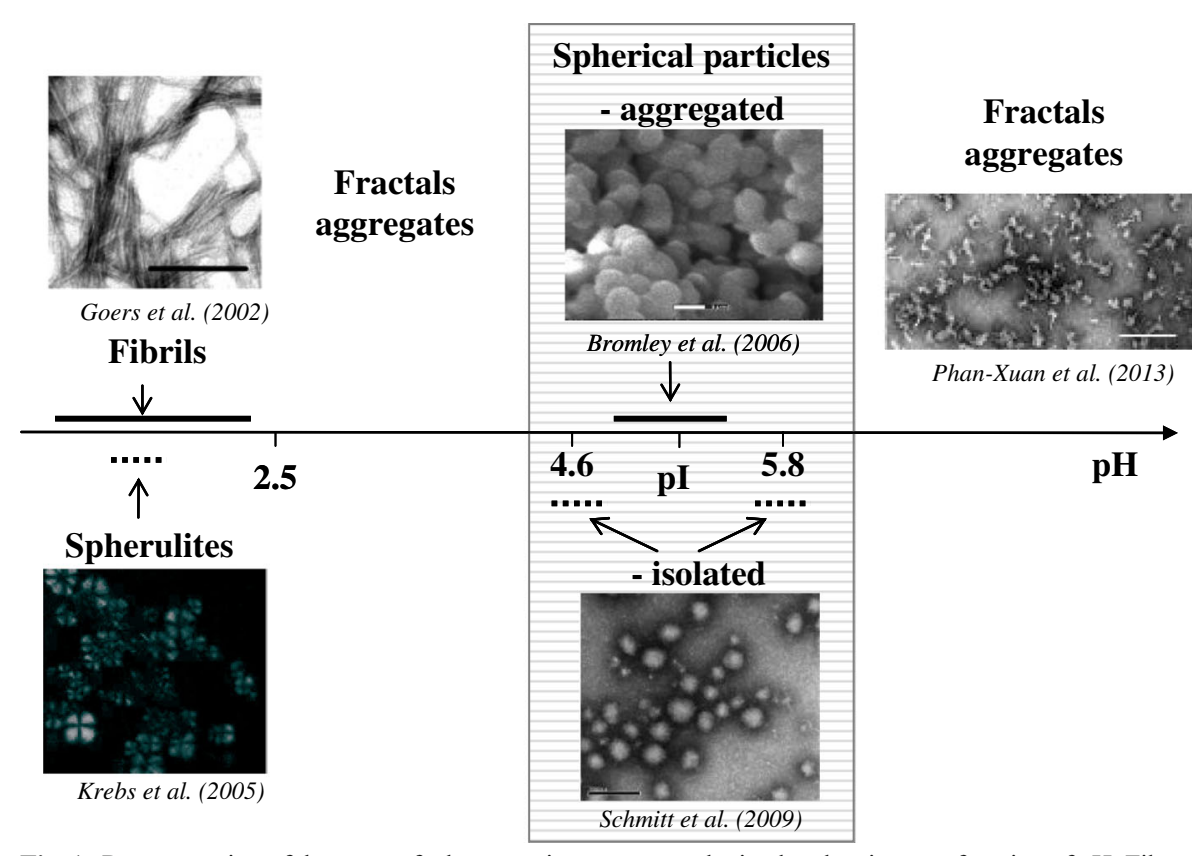

Fig. 1 Representation of the types of whey protein aggregates obtained on heating as a function of pH: Fibers (reprinted from Goers et al. (2002) with kind permission from American Chemical Society); Spherulites (reprinted from Krebs et al. (2005) with kind permission from Elsevier); Isolated spherical particles (reprinted from Schmitt et al. (2009) with kind permission from American Chemical Society); Aggregated spherical particles, (reprinted from Bromley et al. (2006) with kind permission from Springer Science and Business Media); Fractal aggregates (reprinted from Phan-Xuan et al. (2013) with kind permission from American Chemical Society)

obtained at higher protein concentration (Nicolai and Durand 2013) (Fig. 1). The size of the aggregates increased continuously with protein concentration up to the critical concentration of gelation. The density of branching inside the fractal aggregates, and then the density of the aggregates, increases by increasing ionic strength due to the decrease in electrostatic repulsions between flexible strands (Baussay et al. 2004).

Formation of twisted fibrils was also reported at neutral $\mathrm{pH}$ after heating $\beta-\mathrm{LG}$ at $90{ }^{\circ} \mathrm{C}$. Interestingly, addition of reducing sugar before heating in the same conditions slowed down the aggregation/fibrillation kinetics of heated $\beta-\mathrm{LG}$, leading to a mixture of short fibrils and polydisperse aggregates (Pinto et al. 2012). In this study, we showed that glucose affected the growing step of covalent aggregates but not the initial denaturation/aggregation step of native protein. Concomitantly, we found that glucose affected also the aggregation kinetic of $\beta$-casein $(\beta-\mathrm{CN})$ into spherical particles but in opposite manner as glucose promoted the formation of covalently linked spherical particles larger than those observed without glucose (Pinto et al. 2014). Additional structural studies could enlighten us on the exact chemical nature of crosslinking involved in the two types; $\beta-\mathrm{LG}$ versus $\beta-\mathrm{CN}$ aggregates. In parallel, $\beta-\mathrm{LG}$ aggregates produced in the presence of glucose, especially twisted fibrils, were shown to be more resistant to simulated gastrointestinal digestion (Pinto et al. 2014). However, the formation of such enzymatically resistant aggregates was induced under severe heating of isolated proteins $\left(90^{\circ} \mathrm{C}, 24 \mathrm{~h}\right)$, and their occurrence in formulated food needs to be 
proved. Also, the functional properties of particles generated from both proteins with and without glucose deserve to be evaluated.

Dry-heating is another means used to denature and to form whey protein aggregates. Compared to heating in solution, the time of dry-heating for reaching a similar level of protein denaturation is usually longer. The size of the aggregates in dry-heated WPI increases (i)with the time of dry heating, (ii) with the $\mathrm{pH}$ increase from 2.5 to 6.5 of the concentrate used to prepare the whey protein ingredients for a fixed dry-heating time, (iii) and with the water activity $\left(\mathrm{a}_{\mathrm{w}}\right)$ of powders (Gulzar et al. 2011, 2012). According to the experimental conditions of dry-heating $\left(\mathrm{pH}, \mathrm{a}_{\mathrm{w}}\right.$, time/temperature), different proportions of residual native proteins, soluble and insoluble aggregates, are recovered in the final powders (Gulzar et al. 2012). Enhanced heat-set gelling properties of reconstituted dry-heated whey protein powders at $10 \%(w / w)$ and $\mathrm{pH} 7$ were found to be directly linked to a higher proportion of soluble aggregates. The maximal gelling properties were achieved earlier when powders were subjected to dry-heating at higher $\mathrm{a}_{\mathrm{w}}$ and $\mathrm{pH}$ values (Gulzar et al. 2012). An optimized combination of the dry heating parameters is thus a good way to improve certain functional properties of whey proteins.

While many ingredients can be formulated using only the whey protein fraction, heating milk yields to co-aggregation of the whey protein and the $\mathrm{k}$-casein $(\mathrm{K}-\mathrm{CN})$, essentially through thiol-disulfide interchange, with a ratio of $1-5$ whey protein to $1 \mathrm{~K}$ CN molecule (Donato and Guyomarc'h 2009). Other caseins may be incorporated to a minor extent through noncovalent binding, especially in conditions that challenge the integrity of the casein micelle, e.g., elevated pH (Menard et al. 2005; Guyomarc'h et al. 2007a). Caseins have the ability to protect globular proteins from extensive heatinduced aggregation (Yong and Foegeding 2010). In $\beta$-LG solution at $\mathrm{pH} 7$ containing the $\mathrm{C}$-terminal part of the $\mathrm{k}-\mathrm{CN}$, called caseinomacropeptide (CMP), a similar effect of $\mathrm{CMP}$ on the size of the aggregates of $\beta-\mathrm{LG}$ was observed even if the denaturation of $\beta$ LG was accelerated (Croguennec et al. 2014). The proposed mechanism is referred to as "chaperone" action of the casein or CMP upon the denaturing globular proteins. This action results mainly from the intrinsically unstructured and the well-separated hydrophilic and hydrophobic domains of the casein and CMP polypeptides (Farrell et al. 2006). In the case of $\mathrm{k}-\mathrm{CN}$, which contains cysteins, it is proposed that thiol-disulfide interaction prevents the "chaperone" protein to dissociate and actually involves the casein into the aggregate. When heating model solution of whey protein isolates at 15 or 20 g.kg, Morand et al. (2011b) found that the hydrodynamic diameter of the resulting aggregates decreased from over $400 \mathrm{~nm}$ to $\sim 100 \mathrm{~nm}$ when $\mathrm{k}-\mathrm{CN}$ was added prior to heating. The presence of as less as $5 \% w / w$ of the total protein as $\mathrm{k}-\mathrm{CN}$ is sufficient to divide the size of the aggregates by about twofold (Morand et al. 2011a). On the other hand, whey proteins reciprocally protect $\mathrm{K}-\mathrm{CN}$ (glycosylated and unglycosylated forms) from extensive fibrillation (Fig. 2); $\beta$-LG has a higher effect than $\alpha$-LA. Hence, either the whey proteins or the $\mathrm{k}-\mathrm{CN}$ assemble into large structures ( $\mu \mathrm{m}$ scale) when heated in isolated form, but assemble into small aggregates $(0.1-\mu \mathrm{m}$ scale) when heated together (Guyomarc'h et al. 2009; Morand et al. 2011a). Equally, the shape of the co-aggregated whey protein and $\mathrm{K}-\mathrm{CN}$ is intermediate between branched, fractal aggregates of whey proteins (Nicolai and Durand 2013) and elongated fibrils of $\mathrm{K}-\mathrm{CN}$ (Leonil et al. 2008). Reports describe 100 -nm diameter "noodle-like," "round" or "oval-shaped" aggregates in milk when heated in various conditions that mainly 
Fig. 2 Kinetic of the fibril growth of carboxymethylated $\mathrm{K}$-casein in the absence (full sym$b o l)$ and in the presence of different concentrations of $\beta-\mathrm{LG}$ ( $20 \mu \mathrm{M}$, open circle; $50 \mu \mathrm{M}$, open diamond; $125 \mu \mathrm{M}$, open triangle; $300 \mu \mathrm{M}$, open square) monitored by the enhancement of thioflavin fluorescence intensity at $37^{\circ} \mathrm{C}$ in $10 \mathrm{mM}$ sodium phosphate buffer ( $\mathrm{pH}$ 6). In all samples, K-casein and thioflavin concentration was 50 and $240 \mu \mathrm{M}$, respectively

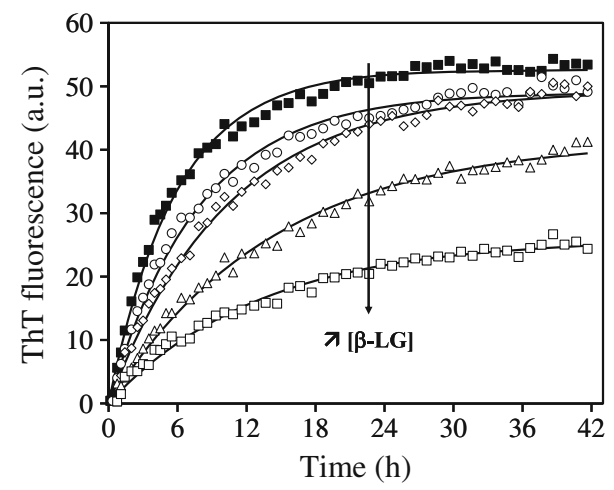

affected the proportion of $\mathrm{k}-\mathrm{CN}$ in the aggregates and, hence, the propensity for anisotropic shape (for review, see Donato and Guyomarc'h (2009). Finally, the density of the aggregates is also somewhat dependent on their composition. When either $\mathrm{K}-\mathrm{CN}$ or sodium caseinate was co-heated with whey protein isolate in model solutions, density of the resulting aggregates was found to be lower than that of whey protein-based aggregates (Guyomarc'h et al. 2009). The explanation may lie in the changes that were observed in the secondary structure of the proteins inside the aggregates, although only slightly dependent on the proportion of $\mathrm{K}-\mathrm{CN}$. Increasing $\mathrm{K}-\mathrm{CN}$ in model aggregates resulted in lower levels of intramolecular $\beta$-sheets, $\alpha$-helix, and/or disordered structures (Morand et al. 2011b). In contrast, when $\beta-\mathrm{LG}$ and CMP carry opposite charge ( $\mathrm{pH} 4.0)$, CMP promoted the noncovalent aggregation of nonnative forms of $\beta-\mathrm{LG}$ (unfolded monomers and small aggregates) resulting in a rapid phase separation. Such phase separation did not occur in the presence of native $\beta-\mathrm{LG}$, indicating that hydrophobic associations between CMP and residues exposed during heatdenaturation of $\beta$-LG molecules are involved (Croguennec et al. 2014).

Under specific $\mathrm{pH}$ conditions, whey proteins with opposite net charge, $\beta$-LG and LF or $\alpha$-LA and LF, are shown to co-assemble in the absence of external energy input and form well-defined microspheres (Bouhallab and Croguennec 2014). The optimal pH condition for protein co-assembly is found when the molar charge equivalent ratio is reached. The driving forces of protein co-assembly are intermolecular electrostatic interactions and the release of water molecules or co-ions from the protein's surface (Bouhallab and Croguennec 2014). Similar mechanisms are responsible for the spontaneous assembly of $\mathrm{LF}$ with $\alpha-\mathrm{CN}, \beta-\mathrm{CN}$, or $\mathrm{k}-\mathrm{CN}$ (Anema and de Kruif 2012). Nanotubes of $\alpha$-LA of several micron length, and external and internal diameters of $20 \mathrm{~nm}$ and about $8 \mathrm{~nm}$, respectively, are another form of protein self-assembly requiring low-energy input. To date, $\alpha$-LA is the only protein proved to form such spectacular structure. The formation of nanotubes requires a limited hydrolysis of the $\alpha$-LA backbone by a serine protease and under specific conditions such as the protein concentration, the presence of specific divalent cations, and the hydrolysis conditions, $\alpha$-LA fragments self-assemble into nanotubes (Graveland-Bikker and de Kruif 2006). These reversible structures were suggested to be used as vehicles for the protection and the controlled release of bioactives. 


\subsubsection{Surface properties}

Surface charge and apparent isoelectric $p H$ values The apparent $p I$ of whey protein aggregates is estimated at the interpolation to 0 of their electropheric mobility as measured by laser Doppler velocimetry. The $p I$ of colloidal particles should depend on the salt phase used to suspend the aggregates, but Jean et al. (2006) reported that the mobility of aggregates present in the soluble phase of milk heated at $90{ }^{\circ} \mathrm{C}$ for $10 \mathrm{~min}$ does not depend on the ionic strength. They measured the $p I$ of the natural serum aggregates suspended either in a milk ultrafiltrate or in a $20 \mathrm{mM}$ imidazole $/ 50 \mathrm{mM}$ $\mathrm{NaCl} / 5 \mathrm{mM} \mathrm{CaCl}_{2}$ buffer or in the latter buffer diluted threefold in water and found $\mathrm{pI}$ 4.5 at $25^{\circ} \mathrm{C}$. A value of 4.4 was also reported by Guyomarc'h et al. (2007b). At pH 6.7, in milk ultrafiltrate, aggregates have a $\xi$-potential of -17 to $-19 \mathrm{mV}$ that provided them some stability. When Jean et al. (2006) prepared artificial aggregates by heating a mixture of $\beta-\mathrm{LG}, \alpha-\mathrm{LA}$, and $\mathrm{k}-\mathrm{CN}$ in a $20-\mathrm{mM}$ buffer, the $p I$ of the obtained aggregates was $\sim 4.7$. The $\xi$-potential of the artificial aggregates in milk ultrafiltrate was $\sim-20 \mathrm{mV}$ at $\mathrm{pH}$ 6.7. This value is in the range of the values reported for unheated $\beta$-LG at pH 6.7 (Schmitt et al. 2009). After heat-treatment, the absolute negative charge of $\beta$-LG aggregates increased by about $10 \mathrm{mV}$ compared to unheated $\beta$-LG. This increase is much more drastic at $\mathrm{pH} 5.7-5.9$, the $\mathrm{pH}$ range of formation of stable suspensions of monodispersed spherical particles on heating, where a $\xi$-potential of -40 to $-50 \mathrm{mV}$ was reported (Schmitt et al. 2009). Below the $\beta$-LG $p I$, the charge of the aggregates is also maximum in the $\mathrm{pH}$ range of formation of stable spherical particles ( $\mathrm{pH} 4.5-4.7$ ), suggesting that the exceptional stability of the spherical particles is governed by electrostatic repulsions (Donato et al. 2009). At sufficient protein concentration, soluble aggregates formed on heating can associate together at room temperature and form a gel when their charges are shielded by adding salt or reducing $\mathrm{pH}$ close to $\mathrm{pI}$ of aggregate (Bryant and Mcclements 1998).

Another way to evaluate the influence of aggregate surface charge on the functional properties of dairy product is to modify preformed heat-induced aggregates with biochemical or chemical grafting as shown in the Fig. 3(D) (adapted from Famelart et al. 2011). Morand et al. (2011b) prepared soluble aggregates with a hydrodynamic diameter around $100 \mathrm{~nm}$ from whey protein solutions heated in the absence and in the presence of 15 to $40 \% w / w$ of $\mathrm{K}-\mathrm{CN}$. These aggregates were very similar in terms of surface hydrophobicity, size and internal structure but differed regarding their $p I$. Pure whey protein aggregates had a $p I$ of 4.7 , as measured in milk ultrafiltrate, a value which decreased up to 4.3 with addition of $40 \% \mathrm{k}-\mathrm{CN}$ in the mixture. This decrease in $p I$ value is due to the respective $p I$ values of whey proteins and $k-\mathrm{CN}$, i.e., 5.2 and 4.0, respectively. The ability of these aggregates to promote glucono-delta-lactone (GDL)induced acid gelation of milk proteins at $35^{\circ} \mathrm{C}$ in model systems containing $40 \mathrm{~g} . \mathrm{kg}^{-1}$ casein micelles and 10 g. kg ${ }^{-1}$ aggregates suspended in milk ultrafiltrate was evaluated. The results showed a slight decrease in the gelation $\mathrm{pH}$ from 5.6 to 5.3 correlated with the decrease of the $p I$ of the aggregates, without significant effect on the textural or microstructural properties of acid gels.

In another paper, Morand et al. (2012b) produced whey protein aggregates by heating whey protein solutions in the same conditions as used by Vasbinder et al. (2004), i.e., $68.5^{\circ} \mathrm{C}$ for $2 \mathrm{~h}$. Then the surface charge of the aggregates was modified by succinylation or methylation. The grafting of a succinyl group on the lysine 


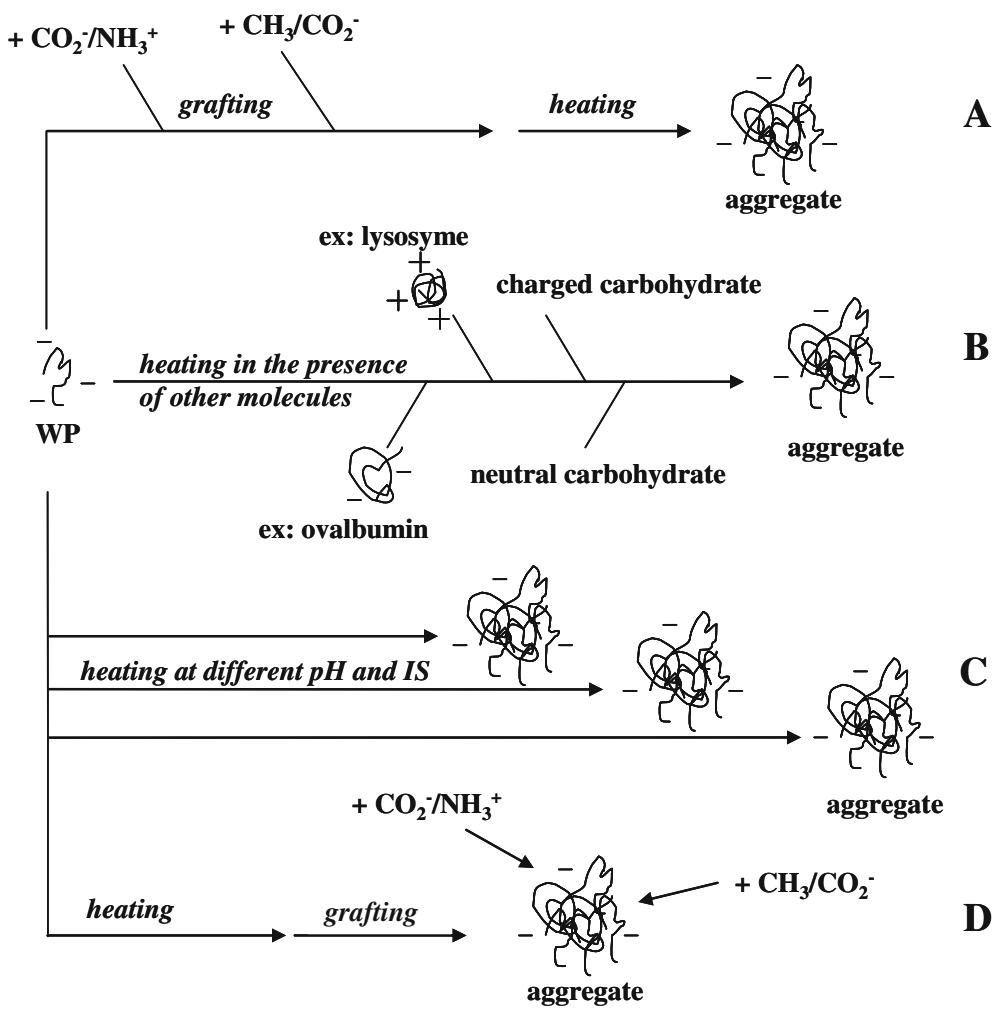

Fig. 3 Scheme of different available pathways to modify the isoelectric $\mathrm{pH}$ value $(p I)$ or the charge of heatinduced whey protein aggregates. $A$ by the chemical or biochemical grafting (succinylation, $+\mathrm{CO}_{2}{ }^{-} / \mathrm{NH}_{3}{ }^{+}$; methylation, $+\mathrm{CH}_{3} / \mathrm{CO}_{2}{ }^{-}$) of whey proteins (WP) before heat treatment; $B$ by heating whey proteins in the presence of other molecules (proteins with different $p I$; neutral or charged carbohydrates); $C$ by modifying the physicochemical conditions ( $\mathrm{pH}$ and ionic strength (IS)) before the heat treatment; $D$ by chemical or biochemical grafting of the heat-induced aggregates (adapted from Famelart et al. 2011)

residues or of a methyl group on carboxyl groups of proteins, respectively, reduced or increased the $p I$ of the aggregates due to the substitution of a positive group by a negative one, or to the neutralization of a negative group, respectively. The modified aggregates had similar hydrodynamic diameter of around $130 \mathrm{~nm}$ but exhibited different $p I$ ranging from 3.2 to 5.3. These authors tested the acid gelation of control and modified aggregates, alone or in mixtures with casein micelles, as previously described. They reported that the $p I$ of the aggregates determined the $\mathrm{pH}$ of gelation in both studied systems, i.e., aggregates alone or mixed with casein micelles. Concerning textural properties of acid gels, an optimal $p I$ of the aggregates at 4.0-4.4 was evidenced for maximal firmness of the gel; it is noteworthy adding that this is close to the $p I$ of the natural serum aggregates found in milk heated at $90^{\circ} \mathrm{C}$ for $10 \mathrm{~min}$.

Surface hydrophobicity The surface hydrophobicity of whey proteins increases significantly upon heat-denaturation due to the exposition of hydrophobic patches on the surface of the unfolded molecular species. When their surface charge is not too high, 
unfolded proteins and aggregates come close together and the exposed hydrophobic patches are able to initiate aggregation reactions. Like the surface charge, the surface hydrophobicity of the aggregates constitutes an important parameter to control their solubility and reactivity. Such modifications could have desired effects such as improvements of the foaming and emulsifying properties (Moro et al. 2001).

To evaluate the contribution of the aggregate's surface hydrophobicity on acid gelation of dairy mixtures, Morand et al. (2012a) produced heat-induced whey protein aggregates that were modified by grafting with chemical groups of ranged hydrophobicity. Whey protein aggregates were either succinylated using succinic anhydride or acylated using acetic, butanoic, or hexanoic anhydrides in order to obtain aggregates of increasing order of hydrophobicity. The hydrophobicity of aggregates was evaluated through their affinity for the nonionic 6-propionyl2-( $N, N$-dimethylamino)-naphtalene (PRODAN) hydrophobic probe, by the ratio of the emitted fluorescence to the concentration of protein. It is expressed as the protein surface hydrophobicity or PSH in $\mathrm{kg}^{-\mathrm{g}^{-1}}$. The whey protein aggregates exhibited surface hydrophobicity ranging from $\sim 3,000$ to $16,000 \mathrm{~kg}^{-g^{-1}}$. Such modifications also affected the net charge of the modified aggregates as the hydrophobic chemical groups were attached on lysine residues and some carried a negative charge. For low level of grafting, the hydrodynamic diameter of the modified aggregates was around $90 \mathrm{~nm}$, against $120 \mathrm{~nm}$ for aggregates with high level of grafting. The acid gelation of suspensions of control (unmodified) or grafted aggregates, alone or in mixture with casein suspensions, was studied. An increase of the surface hydrophobicity of aggregates having the same $p I(\sim 3.7)$ induced a significant increase of the $\mathrm{pH}$ of gelation and of the maximum storage modulus $G^{\prime}$ of the acid gels made from suspensions of aggregates alone. With the most hydrophobic aggregates, gels began to form early after the addition of GDL and as soon as the value of $\mathrm{pH}$ reached $\sim 6.0$. Concerning the mixtures containing aggregates and casein micelles suspended in milk ultrafiltrate, a limited increase of the surface hydrophobicity of the aggregates from $\sim 3,000$ to $6,000 \mathrm{~kg} . \mathrm{g}^{-1}$ induced an increase of the $\mathrm{pH}$ of gelation of the solutions, while for higher level of grafting, the gelation was too fast to measure correctly the gelation $\mathrm{pH}$. Indeed, gelation occurred at $\mathrm{pH}>6.0, \mathrm{pH}$ range for which GDL induces a rapid $\mathrm{pH}$ drop. It is also for this limited increase in the surface hydrophobicity of the aggregates from $\sim 3,000$ to $6,000 \mathrm{~kg} \cdot \mathrm{g}^{-1}$ that the $\mathrm{G}^{\prime}$ dramatically increased, from 300 to $2,000 \mathrm{~Pa}$. With the aggregates having larger hydrophobicity, from 6,000 to $16,000 \mathrm{~kg} \cdot \mathrm{g}^{-1}$, the storage modulus increases at the beginning of the acidification and then dropped, so that the final value of G' at $\mathrm{pH} 4.5$ was lower, around $500 \mathrm{~Pa}$. In the latter cases, the authors suspected an excessive contraction of the gel or syneresis as a significant whey separation was visible during rheological measurements. Moreover, increasing the surface hydrophobicity of the aggregates led to coarser acid mixed gels, with more clustered chains of particles and larger pore size. The authors assumed the effect of adding hydrophobic whey protein aggregates in acid casein gel was in some way similar to the effect of renneting. Indeed, renneting increases the surface hydrophobicity of casein micelles by releasing the hydrophilic C-terminal part of the $\mathrm{K}$-casein in the serum phase and creating hydrophobic patches on their surface. Similarly, the hydrophobic whey protein aggregates could first interact with the 
Fig. 4 HP-GPC profiles of whey protein samples (M-WPI, model whey protein isolate obtained by mixing purified $\beta$-LG and $\alpha$-LA in the same amount as in commercial WPI; M-WPI + L, M-WPI containing the same amount of lactose as in C-WPI; C-WPI, commercial WPI (Prolacta 95, Lactalis, France)) nonheated and dryheated at two different $\mathrm{pH}$ (2.5 and 6.5). Before dry heating (black line), and after dry heating for $8 \mathrm{~h}$ (dashed line), and $24 \mathrm{~h}$ (dotted line). $\alpha$-LA corresponds to $\alpha$-lactalbumin monomer, while $\beta$-LG corresponds to the monomer and dimer equilibrium of $\beta$-lactoglobulin. Dry-heating was performed at $100{ }^{\circ} \mathrm{C}$ under $a_{\mathrm{w}}=0.23$

micelle surface and create hydrophobic "patches" that could then lead to high attractive forces contracting and expulsing whey from the gel. Combining the studies on the surface properties of the aggregates (charge and hydrophobicity), our group indicated that the aggregates are destabilized at higher $\mathrm{pH}$ when hydrophobicity and $p I$ of aggregates increased, and allowed the gelation of whey protein aggregates alone or in mixture with casein micelles to happen at a higher $\mathrm{pH}$ value.

\subsubsection{Type of interactions}

Whey protein aggregates produced in solutions at neutral $\mathrm{pH}$ are stabilized mainly via intermolecular disulfide bonds and noncovalent interactions (Hoffmann and van Mil 1999). The balance between both types of interactions is tuneable by changing the ionic strength, $\mathrm{pH}$, and the temperature of heating as indicated in the detailed review of De Wit (2009) on the thermal behavior of $\beta$-LG. Caseinomacropeptide (CMP), which is present in most of commercial whey protein ingredients, also modified the structure of whey protein aggregates. Increasing the amount of CMP in $\beta$-LG solutions resulted in a decrease of the number of intermolecular disulfide bonds within the aggregates formed on heating (Croguennec et al. 2014). At low pH, the reactivity of sulfhydryl groups is reduced and the aggregates are mainly stabilized by noncovalent interactions. Interestingly, it was observed that disulfide bonds are the main intermolecular covalent bonds in the aggregates formed by dry heating of a mixture of purified whey proteins $(80 \% \beta$-LG and $20 \% \alpha$-LA) at $\mathrm{pH}$ value as low as 2.5 . At $\mathrm{pH}>4.5$, intermolecular covalent interactions resistant to reducing agent, e.g., DTT, hence other than disulfide bonds, are also formed within the aggregates; their occurrence increased with increasing the $\mathrm{pH}$ for dry heating. These interactions are not identified yet but they are rather limited within the heat-induced aggregates formed in solutions. Similar results were obtained during the dry heating of commercial WPI (Gulzar et al. 2011) but the contribution of covalent bonds other than disulfide bond was enhanced in all range of $\mathrm{pH}$ studied (from $\mathrm{pH} 2.5$ to 6.5 ). It is noteworthy that commercial whey proteins contain lactose. Whey protein ingredients with the lowest content of lactose still contain $<4 \%(w / w)$ of free lactose on a dry matter basis. We observed by comparing dry heatinduced denaturation/aggregation of a mixture of purified whey proteins in the absence (M-WPI on Fig. 4) or in the presence (M-WPI+L on Fig. 4) of lactose that the presence of small amounts of lactose has a dramatic influence on the aggregates formed at $\mathrm{pH}$ 6.5 , but not at $\mathrm{pH} 2.5$. The different behavior of M-WPI+L compared to a commercial WPI (C-WPI on Fig. 4) during dry heating at $\mathrm{pH} 2.5$ was explained by the fact that a part of the lactose molecules in C-WPI are bound to whey proteins before dry heating and the condensation products decomposed during dry heating. In the M-WPI+L samples, the condensation reaction of lactose with whey proteins is the limiting step and the subsequent reactions leading to aggregates are hindered. This suggests that 

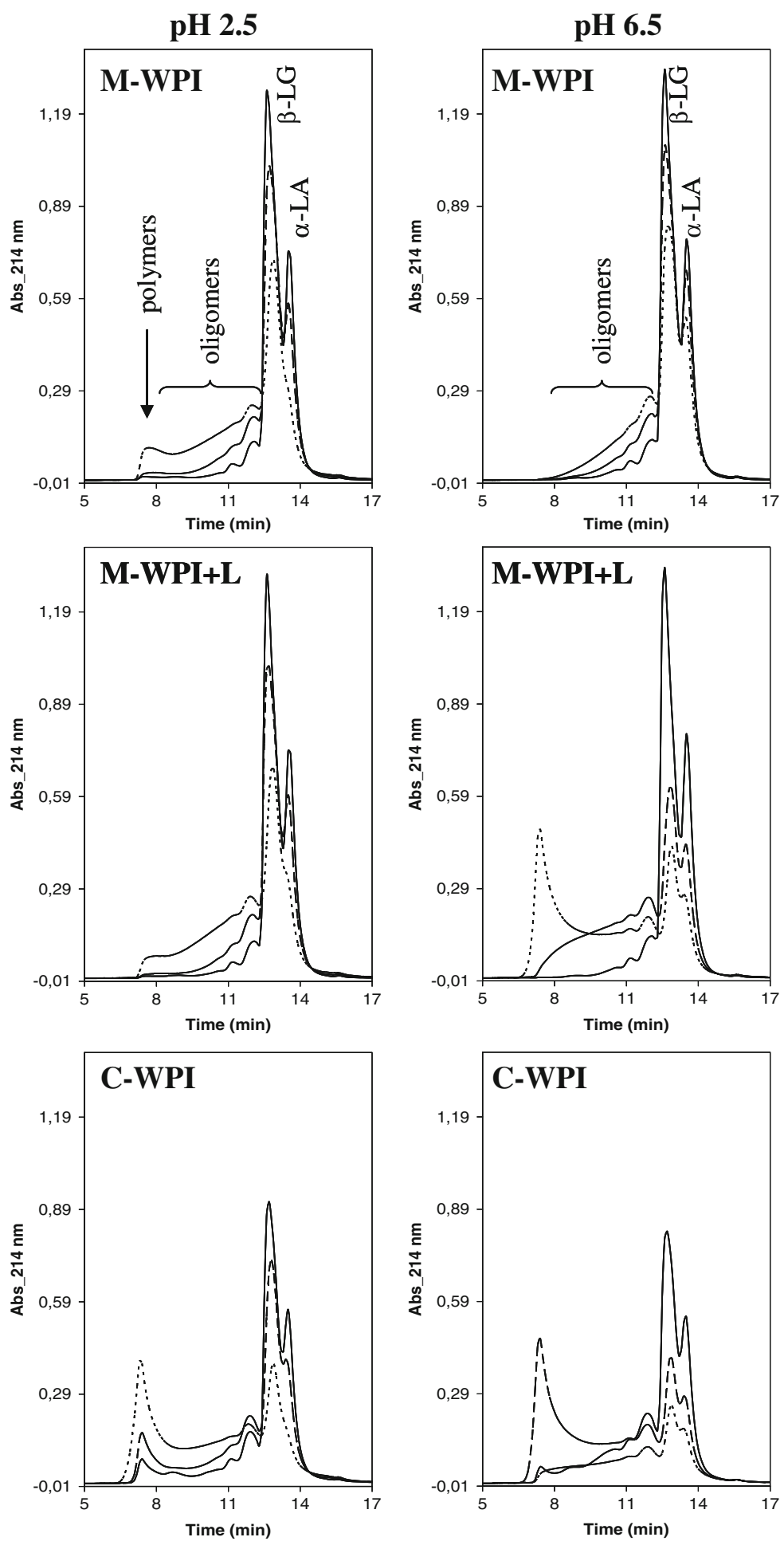

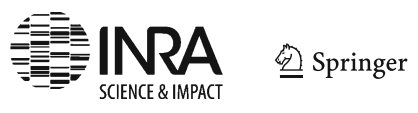


some of the intermolecular covalent bonds observed in dry-heated C-WPI involved the degradation products of Maillard intermediates such as $\alpha$-dicarbonyl compounds, which are formed preferentially at $\mathrm{pH} 6.5$ during Maillard reaction.

Milk acid gels can also be viewed as the stepwise assembly of, first, the whey proteins and caseins into aggregates upon heating and, second, (the connection) of these aggregates together upon destabilization of the milk by acidification. At each step, interactions are formed that may fall into two categories, namely covalent disulfide bonds that are rigid and noncovalent low-energy bonds that are weaker. Hence, it is expected that changes in the type of interactions involved on either step of the process may affect the final texture of the acid gel. A first approach is either to block or to release free thiol groups at the surface of preformed whey protein $/ \mathrm{k}-\mathrm{CN}$ aggregates in heated skim milk, in order to establish the importance of thiol-disulfide exchanges upon acid gel formation. Nguyen et al. (2012) verified that these treatments merely affected the protein assemblies in milk, i.e., the casein micelles or the aggregates, and did not affect their distribution between the serum and colloidal phases. When adding the thiol-blocking reagent $N$-ethyl-maleimide (NEM) into heated skim milk, Famelart et al. (2013) observed little change in the kinetic of formation and in final characteristics of model acid gels: the final elastic modulus of the gel did not decrease significantly upon the NEM addition; only the yield properties such as the firmness at large strain was significantly reduced. These results were confirmed by Nguyen (2014) and contradicted former results by Vasbinder et al. (2003) or Lucey et al. (1998) who reported decreased elastic moduli of acid gels using a similar approach. In fact, Lakemond and van Vliet (2008a, 2008b) reported opposite effects of the addition of NEM on the acid gelation of heated milk, in relation to the $\mathrm{pH}$ at which milk was heat-treated. When heated at $\mathrm{pH}$ 6.2, no effect of NEM addition appeared, while when milk was heated at $\mathrm{pH}$ 6.9, NEM addition leads to significant decreases in gelation $\mathrm{pH}$ and gel stiffness. Another explanation is that the amount of free thiols in heated milk is low, as discussed below, and blocking them could be insignificant on the decrease of the final elastic modulus of the acid gels. In contrast, when submitting preheated milk to a reductive reagent such as $\beta$-mercaptoethanol, Nguyen (2014) showed that the final elastic modulus of model acid gels can be increased from $\sim 200$ to $300 \mathrm{~Pa}$. Furthermore, the yield stress of the gels increased, i.e., they resisted to larger deformation than control gels. These results support the idea that thiol-disulfide exchanges can occur during acidification, but are not necessary for the elastic modulus to reach values of hundreds $\mathrm{Pa}$. The reason why blocking free thiol groups did not result in significant decrease of the final elastic modulus of the acid gels may be quantitative. If considering only the free thiol of $\beta$-LG in heated milk, engaged in thiol-disulfide interchanges (i.e., conservation of the free thiol groups), one can calculate that only about $0.2 \mathrm{mM}$ of free thiols are present on the aggregates and can be blocked by NEM, which represents a small range of variation to study the effect of thiol-disulfide exchanges during acid gelation. On the other hand, the number of free thiols can be increased threefold by using reductive reagent such as $\beta$-mercaptoethanol, only considering $\mathrm{K}$-casein, which is preferably reduced in comparison to whey proteins (Nguyen et al. 2012, 2013a) and part of the $\beta$-LG (BSA being an even greater reservoir of cysteins). So, the range of thiol concentrations that can be explored when blocking the thiol groups is much lower than the one accessible when reducing disulfide bonds and hence, effects are more likely to be observed, if any. Figure 5 summarizes the 

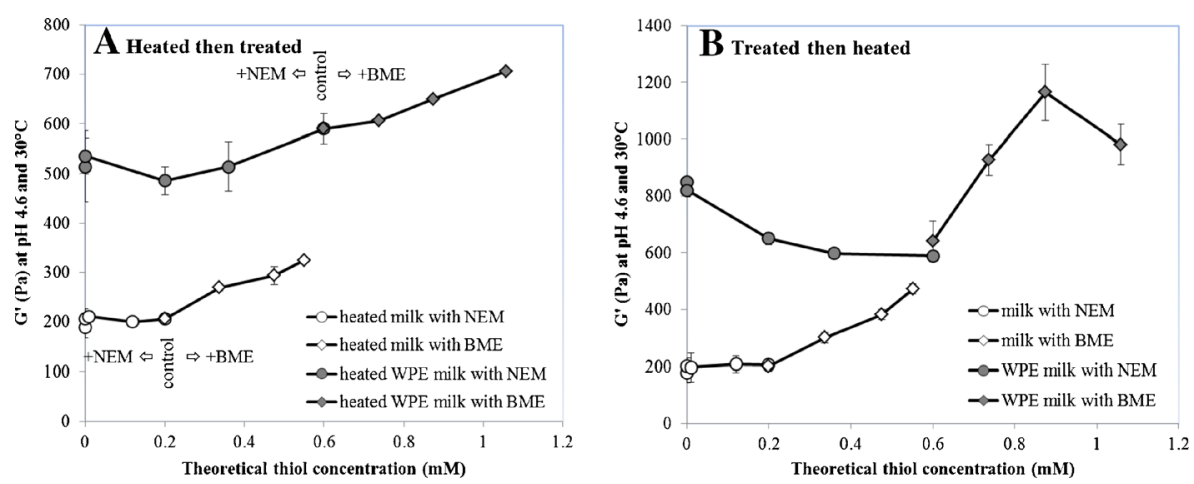

Fig. 5 Effect of the concentration of free thiol groups on the final elastic modulus, G' (Pa) of acid gels of heated $\left(80{ }^{\circ} \mathrm{C}, 30 \mathrm{~min}\right)$ skim milk (milk, white symbols $)$ or of heated $\left(80^{\circ} \mathrm{C}, 30 \mathrm{~min}\right)+1 \% \mathrm{w} / \mathrm{w}$ whey proteinenriched skim milk (WPE-milk, gray symbols) obtained after incubation with $2 \% w / w$ GDL at $30{ }^{\circ} \mathrm{C}$ for $3 \mathrm{~h}$. The concentration of free thiol groups was modified using either NEM (circles) or $\beta$-ME (diamonds) after (a) or prior (b) heat-treatment. Figure adapted from the data by Nguyen 2014 (PhD thesis)

results obtained by Nguyen (2014) when submitting preheated skim milk or preheated whey protein-enriched skim milk (WPE-milk) to either NEM (to block the free thiol groups) or $\beta$-mercaptoethanol. It clearly shows that while blocking the $0.2 \mathrm{mM}$ free thiol groups has little consequence on the final G' of acidified milk, blocking the free thiol groups of WPE-milk or releasing the free thiol groups on either sample can significantly increase the final firmness of the gels.

In order to modify the balance between covalent (strong) and noncovalent (weak) interactions in the gels, a second approach is to modify the nature of the bonds involved in the formation of the heat-induced aggregates themselves. To do this, thiols are either blocked or released using chemical reagents, prior to heating the milk (Fig. 5b). When thiol-blocking NEM is added to milk or milk supplemented with $1 \% \mathrm{w} / \mathrm{w}$ whey protein isolate, the irreversible denaturation of whey proteins on heating was decreased. Thus, up to $40 \%$ of the total whey proteins in skim milk and up to $80 \%$ in WPE-milk remained soluble at $\mathrm{pH} 4.6$ after heat-treatment at $80{ }^{\circ} \mathrm{C}$ for $30 \mathrm{~min}$. However, some heat-induced aggregates were formed and the final elastic modulus of the resulting acid gels was only decreased by $20-30 \%$ compared to milk without added NEM and subjected to the same treatment. The yield properties also changed as the gels were fractured more easily upon large deformation (Nguyen et al. 2014). These results indicated that the presence of disulfide bonds inside the heat-induced aggregates is important, but not essential, as milks containing thiol-blocking agent gave firm set acid gels of $\sim 200 \mathrm{~Pa}$ (Fig. 5b, white circles). When NEM is added to milk supplemented with $1 \%$ whey protein isolate, the final elastic modulus of the acid milk gels was conversely increased (Fig. 5b, grey circles). Nguyen et al. (2014) attributed this effect to a conjunction of increasing number of heat-induced aggregates (due to the added WPE) and of increasing possibility for rearrangement during gel formation (due to the thiol-blocking agent). Also, they observed the dissociation of caseins in WPE-milk heated in the presence of NEM. K-casein that is not covalently engaged to whey proteins in the presence of NEM has a higher propensity to stabilize the $\alpha$ - and $\beta$ caseins that dissociate upon heating, in the form of small nonsedimentable assemblies. A proportion of casein into dissociated form is suspected to enhance the firmness of acid milk gels. 
To increase the number of free thiol groups in the milk prior to heating, Nguyen et al. (2012, 2013b) used up to $7 \mathrm{mM} \beta$-mercaptoethanol to reduce disulfide bonds. Interestingly, this treatment selectively affected the $\mathrm{k}-\mathrm{CN}$, probably because this protein is found in polymeric form where the intermolecular disulfide bonds are more exposed to reactant than the intramolecular disulfide bonds of the globular proteins (Nguyen et al. 2012, 2013a). Upon heat-treatment of skim milks, supplemented with whey protein isolate or not, the presence of more free thiol groups on the $\mathrm{k}-\mathrm{CN}$ (reduced samples) was associated with the formation of larger aggregates, containing less $\mathrm{k}-\mathrm{CN}$ in proportion, and more largely associated with the surface of casein micelles than in control milks. It was proposed that the reduced $\mathrm{k}-\mathrm{CN}$ competed with the $\beta$ lactoglobulin to initiate the heat-induced aggregate formation, thus acting as an "anchor" to bind the whey protein to the casein micelle surface. Possibly, the number of sites where the whey protein could interact with the casein micelle increased as the $\mathrm{K}$ $\mathrm{CN}$ polymers were reduced. As the $\mathrm{K}-\mathrm{CN}$ was reduced, it became monomeric which accounted for its lower proportion in the aggregates, and hence was less able to be a "chaperone" to the denatured whey proteins resulting in larger-sized aggregates. In the aggregates, the proportion of $\beta$-lactoglobulin aggregated through disulfide bonds did not change upon $\beta$-mercaptoethanol addition and heat-treatment, but $\alpha$-lactalbumin significantly engaged into more intermolecular disulfide bonds than in control milk. Acid gels made of milk preheated in the presence of $\beta$-mercaptoethanol exhibited more than twofold increase in the final elastic modulus compared to control, without significant effect on the gel microstructure (Fig. 5b, white and grey diamonds) (Nguyen et al. 2013a). Therefore, freeing thiol groups prior to heating proved a significant way to increase the final firmness of the gels, although the specific roles of the $\mathrm{k}-\mathrm{CN}, \alpha$-lactalbumin and $\beta$-lactoglobulin is still under investigation.

Besides the aggregates described above that contain covalent bonds, the microspheres formed by the co-assembly of whey proteins are stabilized only by noncovalent, low-energy interactions. Compared to the former that are stabilized by strong and irreversible intermolecular interactions, the microspheres are reversible when the surface charge of the protein constituting the microspheres are shielded by ionic strength or $\mathrm{pH}$ change. Understanding the mechanism of co-assembly and disassembly of the protein microspheres paved the way for the development of "switchable" carrier for selected molecules (Bouhallab and Croguennec 2014; Tavares et al. 2014).

\section{Conclusion: perspectives}

Heat treatment is still the predominant mean to create various structures from whey proteins even if plausible alternatives exist as indicated by the controlled self-assembly of $\alpha$-LA into nanotubes or the co-assembly of LF and $\alpha$-LA or LF and $\beta$-LG into microspheres. Much of the work has been done on model systems using purified proteins or group of proteins that differ significantly from real systems. The presence of other constituents may affect the building of whey protein suprastructures; this was illustrated by the impact of caseins or CMP on the size and shape of heat-induced whey protein aggregates, as well as the type of interactions maintaining proteins together. The addition of major cations such as sodium, calcium, and to a lesser extent potassium and 
magnesium has been studied for a long time in order to modulate whey protein suprastructures and functionalities. In contrast, the effect of anions and trace elements was less investigated even though they could have a huge impact on the denaturation/ aggregation reaction of whey proteins. For instance, copper induced the dimerization of denatured $\beta$-LG through oxidation of the free thiol groups (Bouhallab et al. 2004). The covalent dimers associate further into noncovalent aggregates, the size of which increased with increasing $\mathrm{NaCl}$ content in the medium. This gives suprastructures that differ significantly, at least by the type of interactions maintaining proteins together in the aggregates, from the ones obtained in the absence of copper (Gulzar et al. 2009). In the presence of molecules often recovered in milk protein ingredients such as fatty acids (Le Maux et al. 2012), or phospholipids (Le et al. 2007), the aggregation behavior of the proteins is changed on heating. These examples indicate that controlling the structure of whey protein aggregates is difficult in complex systems even though the structure of the building blocks (native whey proteins) is well known. In addition, processing used for the purification of milk protein ingredients often induce chemical and/or structural modifications such as lactosylation of milk proteins or the loss of water molecules in purified $\alpha$-LA (Gulzar et al. 2013). To our mind, the influence of these modifications on the functional properties of whey protein ingredients is still underestimated. Their consideration could improve the control of formation of supramolecular structure and the reproducibility of whey protein ingredient functionalities. Basic knowledge on the occurrence of such modifications and interactions should help innovation in the industry by continually offering new functional products.

\section{References}

Akkermans C, Venema P, van der Goot AJ, Gruppen H, Bakx EJ, Boom RM, van der Linder E (2008) Peptides are building blocks of heat-induced fibrillar protein aggregates of beta-lactoglobulin formed at pH 2. Biomacromolecules 9:1474-1479

Andoyo R, Guyomarc'h F, Cauty C, Famelart M-H (2014) Model mixtures evidence the respective roles of whey protein particles and casein micelles during acid gelation. Food Hydrocoll 37:203-212

Anema SG, de Kruif CG (2012) Co-acervates of lactoferrin and caseins. Soft Matter 8:4471-4478

Anema SG, Lee SK, Klostermeyer H (2007) Effect of pH at heat treatment on the hydrolysis of k-casein and the gelation of skim milk by chymosin. LWT Food Sci Technol 40:99-106

Arnaudov LN, de Vries R (2007) Theoretical modeling of the kinetics of fibrilar aggregation of bovine betalactoglobulin at $\mathrm{pH}$ 2. J Chem Phys 126:145106

Baker EN, Baker HM (2009) A structural framework for understanding the multifunctional character of lactoferrin. Adv Lact Res 91:3-10

Baussay K, Le Bon C, Nicolai T, Durand D, Busnel JP (2004) Influence of the ionic strength on the heatinduced aggregation of the globular protein beta-lactoglobulin at $\mathrm{pH}$ 7. Int J Biol Macromol 34:21-28

Bernal V, Jelen P (1984) Effect of calcium-binding on thermal-denaturation of bovine alpha-lactalbumin. J Dairy Sci 67:2452-2454

Bolder SG, Vasbinder AJ, Sagis LMC, van der Linden E (2007) Heat-induced whey protein isolate fibrils: conversion, hydrolysis, and disulphide bond formation. Int Dairy J 17:846-853

Bouhallab S, Croguennec T (2014) Spontaneous assembly and induced aggregation of food proteins. Adv Polym Sci 256:67-102

Bouhallab S, Henry G, Caussin F, Croguennec T, Fauquant J, Mollé D (2004) Copper-catalyzed formation of disulfide-linked dimer of bovine beta-lactoglobulin. Lait 84:517-525

Bromley EHC, Krebs MRH, Donald AM (2006) Mechanisms of structure formation in particulate gels of $\beta$ lactoglobulin formed near the isoelectric point. The Eur phys J E 21:145-152

Brownlow S, Cabral JHM, Cooper R, Flower DR, Yewdall SJ, Polikarpov I, North ACT, Sawyer L (1997) Bovine beta-lactoglobulin at 1.8 angstrom resolution - Still an enigmatic lipocalin. Structure 5:481-495 
Bryant CM, Mcclements DJ (1998) Molecular basis of protein functionality with special consideration of coldset gels derived from heat-denatured whey. Trends Food Sci Technol 9:143-151

Chaufer B, Rabiller-Baudry M, Lucas D, Michel M, Timmer M (2000) Selective extraction of lysozyme from a mixture with lactoferrin by ultrafiltration. Role of the physico-chemical environment. Lait 80:197-203

Croguennec T, Leng N, Hamon P, Rousseau F, Jeantet R, Bouhallab S (2014) Caseinomacropeptide modifies the heat-induced denaturation-aggregation process of beta-lactoglobulin. Int Dairy J 36:55-64

Dannenberg F, Kessler H (1988a) Application of reaction-kinetics to the denaturation of whey proteins in heated milk. Milchwiss-Milk Sci Int 43:3-7

Dannenberg F, Kessler HG (1988b) Effect of denaturation of beta-lactoglobulin on texture properties of setstyle nonfat yoghurt. 1. Syneresis. Milchwissenschaft 43:632-635

Dannenberg F, Kessler HG (1988c) Effect of denaturation of beta-lactoglobulin on texture properties of setstyle nonfat yoghurt. 2. Firmness and flow properties. Milchwissenschaft 43:700-704

De Wit JN (2009) Thermal behaviour of bovine beta-lactoglobulin at temperatures up to $150{ }^{\circ} \mathrm{C}$. a review. Trends Food Sci Technol 20:27-34

Domike KR, Donald AM (2007) Thermal dependence of thermally induced protein spherulite formation and growth: kinetics of beta-lactoglobulin and insulin. Biomacromolecules 8:3930-3937

Domike KR, Hardin E, Armstead DN, Donald AM (2009) Investigating the inner structure of irregular betalactoglobulin spherulites. Eur Phys J E 29:173-182

Donato L, Guyomarc'h F (2009) Formation and properties of the whey protein/kappa-casein complexes in heated skim milk - a review. Dairy Sci Technol 89:3-29

Donato L, Schmitt C, Bovetto L, Rouvet M (2009) Mechanism of formation of stable heat-induced betalactoglobulin microgels. Int Dairy J 19:295-306

Famelart MH, Guyomarc'h F, Morand M, Novales B (2011) Agrégation protéique et propriétés gélifiantes et moussantes des protéines laitières - quoi de neuf sur le plan des connaissances? Innov Agron 13:117-132

Famelart M-H, Le NHT, Croguennec T, Rousseau F (2013) Are disulphide bonds formed during acid gelation of preheated milk? Int J Food Sci Technol 48:1940-1948

Farrell HM, Jimenez-Flores R, Bleck GT, Brown EM, Butler JE, Creamer LK, Hicks CL, Hollar CM, NgKwai-Hang KF (2004) Nomenclature of the Proteins of Cows' Milk-Sixth Revision. J Dairy Sci 87: 1641-1674

Farrell HM, Malin EL, Brown EM, Qi PX (2006) Casein micelle structure: what can be learned from milk synthesis and structural biology? Curr Opin Colloid Interface Sci 11:135-147

Forge V, Wijesinha RT, Balbach J, Brew K, Robinson CV, Redfield C, Dobson CM (1999) Rapid collapse and slow structural reorganisation during the refolding of bovine alpha-lactalbumin. J Mol Biol 288:673-688

Goers J, Permyakov SE, Permyakov EA, Uversky VN, Fink AL (2002) Conformational prerequisites for $\alpha$ lactalbumin fibrillation. Biochemistry 41(41):12546-12551

Graveland-Bikker JF, de Kruif CG (2006) Unique milk protein based nanotubes: food and nanotechnology meet. Trends Food Sci Technol 17:196-203

Griko YV, Remeta DP (1999) Energetics of solvent and ligand-induced conformational changes in alphalactalbumin. Protein Sci 8:554-561

Gulzar M, Croguennec T, Jardin J, Piot M, Bouhallab S (2009) Copper modulates the heat-induced sulfhydryl/ disulfide interchange reactions of beta-Lactoglobulin. Food Chem 116:884-891

Gulzar M, Bouhallab S, Jeantet R, Schuck P, Croguennec T (2011) Influence of pH on the dry heat-induced denaturation/aggregation of whey proteins. Food Chem 129:110-116

Gulzar M, Lechevalier V, Bouhallab S, Croguennec T (2012) The physicochemical parameters during dry heating strongly influence the gelling properties of whey proteins. J Food Eng 112:296-303

Gulzar M, Bouhallab S, Jardin J, Briard-Bion V, Croguennec T (2013) Structural consequences of dry heating on alpha-lactalbumin and beta-lactoglobulin at pH 6.5. Food Res Int 51:899-906

Guyomarc'h F (2006) Formation of heat-induced protein aggregates in milk as a means to recover the whey protein fraction in cheese manufacture, and potential of heat-treating milk at alkaline $\mathrm{pH}$ values in order to keep its rennet coagulation properties. A review. Lait 86:1-20

Guyomarc'h F, Mahieux O, Renan M, Chatriot M, Gamerre V, Famelart M-H (2007a) Changes in the acid gelation of skim milk as affected by heat-treatment and alkaline $\mathrm{pH}$ conditions. Lait 87:119-137

Guyomarc'h F, Renan M, Chatriot M, Gamerre V, Famelart M-H (2007b) Acid gelation properties of heated skim milk as a result of enzymatically induced changes in the micelle/serum distribution of the whey protein/kappa-casein aggregates. J Agric Food Chem 55:10986-10993

Guyomarc'h F, Nono M, Nicolai T, Durand D (2009) Heat-induced aggregation of whey proteins in the presence of kappa-casein or sodium caseinate. Food Hydrocoll 23:1103-1110 
Hendrix T, Griko YV, Privalov PL (2000) A calorimetric study of the influence of calcium on the stability of bovine alpha-lactalbumin. Biophys Chem 84:27-34

Hoffmann MAM, van Mil P (1999) Heat-induced aggregation of beta-lactoglobulin as a function of $\mathrm{pH}$. J Agric Food Chem 47:1898-1905

Jayat D, Gaudin JC, Chobert JM, Burova TV, Holt C, McNae I, Sawyer L, Haertle T (2004) A recombinant C121S mutant of bovine beta-lactoglobulin is more susceptible to peptic digestion and to denaturation by reducing agents and heating. Biochemistry (Mosc) 43:6312-6321

Jean K, Renan M, Famelart MH, Guyomarc'h F (2006) Structure and surface properties of the serum heatinduced protein aggregates isolated from heated skim milk. Int Dairy J 16:303-315

Kavanagh GM, Clark AH, Gosal WS, Ross-Murphy SB (2000) Heat-induced gelation of beta-lactoglobulin/ alpha-lactalbumin blends at $\mathrm{pH} 3$ and $\mathrm{pH}$ 7. Macromolecules 33:7029-7037

Kitabatake N, Wada R, Fujita Y (2001) Reversible conformational change in beta-lactoglobulin A modified with $\mathrm{N}$-ethylmaleimide and resistance to molecular aggregation on heating. J Agric Food Chem 49:4011-4018

Kontopidis G, Holt C, Sawyer L (2002) The ligand-binding site of bovine beta-lactoglobulin: evidence for a function? J Mol Biol 318:1043-1055

Korhonen H, Pihlanto A (2006) Bioactive peptides: production and functionality. Int Dairy J 16:945-960

Krebs MRH, Bromley EHC, Donald AM (2005) The binding of thioflavin-T to amyloid fibrils: localisation and implications. J Struct Biol 149(1):30-37

Lakemond CMM, Van Vliet T (2008a) Acid skim milk gels: the gelation process as affected by preheating $\mathrm{pH}$. Int Dairy J 18:574-584

Lakemond CMM, Van Vliet T (2008b) Rheological properties of acid skim milk gels as affected by the spatial distribution of the structural elements and the interaction forces between them. Int Dairy J 18:585-593

Lara C, Adamcik J, Jordens S, Mezzenga R (2011) General self-assembly mechanism converting hydrolyzed globular proteins into giant multistranded amyloid ribbons. Biomacromolecules 12:1868-1875

Le Maux S, Giblin L, Croguennec T, Bouhallab S, Brodkorb A (2012) Beta-lactoglobulin as a molecular carrier of linoleate: characterization and effects on intestinal epithelial cells in vitro. J Agric Food Chem 60:9476-9483

Le Maux S, Bouhallab S, Giblin L, Brodkorb A, Croguennec T (2014) Bovine $\beta$-lactoglobulin/fatty acid complexes: binding, structural, and biological properties. Dairy Sci Technol 94:409-426

Le TT, El-Bakry M, Neirynck N, Bogus M, Hoa HD, van der Meeren P (2007) Hydrophilic lecithins protect milk proteins against heat-induced aggregation. Colloids Surf B: Biointerfaces 60:167-173

Leonil J, Henry G, Jouanneau D, Delage M-M, Forge V, Putaux J-L (2008) Kinetics of fibril formation of bovine k-casein indicate a conformational rearrangement as a critical step in the process. J Mol Biol 381: 1267-1280

Lucey JA, Tamehana M, Singh H, Munro PA (1998) Effect of interactions between denatured whey proteins and casein micelles on the formation and rheological properties of acid skim milk gels. J Dairy Res 65 : 555-567

Mattison KW, Dubin PL, Brittain IJ (1998) Complex formation between bovine serum albumin and strong polyelectrolytes: effect of polymer charge density. J Phys Chem B 102:3830-3836

Mela I, Aumaitre E, Williamson A-M, Yakubov GE (2010) Charge reversal by salt-induced aggregation in aqueous lactoferrin solutions. Colloids Surf B: Biointerfaces 78:53-60

Menard O, Camier B, Guyomarc'h F (2005) Effect of heat treatment at alkaline pH on the rennet coagulation properties of skim milk. Lait 85:515-526

Moore SA, Anderson BF, Groom CR, Haridas M, Baker EN (1997) Three-dimensional structure of diferric bovine lactoferrin at 2.8 angstrom resolution. J Mol Biol 274:222-236

Morand M, Guyomarc'h F, Famelart MH (2011a) How to tailor heat-induced whey protein/kappacasein complexes, as a means to investigate the acid gelation of milk - a review. Dairy Sci Technol 91:97-126

Morand M, Guyomarc'h F, Pezennec S, Famelart MH (2011b) On how k-casein affects the interactions between the heat-induced whey protein/k-casein complexes and the casein micelles during the acid gelation of skim milk. Int Dairy J 21:670-678

Morand M, Dekkari A, Guyomarc'h F, Famelart M-H (2012a) Increasing the hydrophobicity of the heatinduced whey protein complexes improves the acid gelation of skim milk. Int Dairy J 25:103-111

Morand M, Guyomarc'h F, Famelart MH (2012b) Changing the isoelectric point of the heat-induced whey protein complexes affect the acid gelation of skim milk. Int Dairy J 23:9-17

Moro A, Gatti C, Delorenzi N (2001) Hydrophobicity of whey protein concentrates measured by fluorescence quenching and its relation with surface functional properties. J Agric Food Chem 49:4784 4789

Mudgal P, Daubert CR, Foegeding EA (2009) Cold-set thickening mechanism of beta-lactoglobulin at low pH: concentration effects. Food Hydrocoll 23:1762-1770

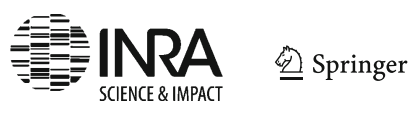


Nguyen NHA (2014) A comprehensive study on the relative importance of disulphide and non-covalent interactions between proteins on the heat-induced aggregation and functional properties of acid milk gels, $\mathrm{PhD}$ thesis, Massey University, Albany.

Nguyen NHA, Wong M, Anema SG, Havea P, Guyomarch F (2012) Effects of adding low levels of a disulfide reducing agent on the disulfide interactions of beta-lactoglobulin and kappa-casein in skim milk. J Agric Food Chem 60:2337-2342

Nguyen NHA, Anema SG, Havea P, Guyomarc'h F, Wong M (2013a) Effect of adding low levels of $\beta$ mercaptoethanol on the disulphide bonds of $\mathrm{K}$-casein and $\beta$-lactoglobulin solutions. Int Dairy J 26:78-82

Nguyen NHA, Wong M, Havea P, Guyomarc'h F, Anema SG (2013b) The protein interactions and rheological properties of skim milk heated in the presence of low levels of reducing agent. Food Chem 138:1604-1609

Nguyen NHA, Wong M, Guyomarc'h F, Havea P, Anema SG (2014) Effects of non-covalent interactions between the milk proteins on the rheological properties of acid gels. Int Dairy J 37:57-63

Nicolai T, Durand D (2013) Controlled food protein aggregation for new functionality. Curr Opin Colloid Interface Sci 18:249-256

Nicolai T, Britten M, Schmitt C (2011) Beta-lactoglobulin and WPI aggregates: formation, structure and applications. Food Hydrocoll 25:1945-1962

Papiz M, Sawyer L, Eliopoulos E, North ACT, Findlay JBC, Sivaprasadaroa R, Jones TA, Newcomer ME, Kraulis PJ (1986) The structure of beta-lactoglobulin and its similarity to plasma retinol-binding protein. Nature 324:383-385

Perez M, Devillegas C, Sanchez L, Aranda P, Ena JM, Calvo M (1989) Interaction of fatty-acids with betalactoglobulin and albumin from ruminant milk. J Biochem (Tokyo) 106:1094-1097

Phan-Xuan T, Durand D, Nicolai T (2013) Tuning the structure of protein particles and gels with calcium or sodium ions. Biomacromolecules 14(6):1980-1989

Phan-Xuan T, Durand D, Nicolai T, Donato L, Schmitt C, Bovetto L (2014) Heat induced formation of betalactoglobulin microgels driven by addition of calcium ions. Food Hydrocoll 34:227-235

Pinto MDS, Bouhallab S, De Carvalho AF, Henry G, Putaux J-L, Léonil J (2012) Glucose slows down the heat-induced aggregation of beta-lactoglobulin at neutral pH. J Agric Food Chem 60:1335-1335

Pinto MS, Leonil J, Henry G, Cauty C, Carvalho AF, Bouhallab S (2014) Heating and glycation of betalactoglobulin and beta-casein: aggregation and in vitro digestion. Food Res Int 55:70-76

Qi XL, Holt C, McNulty D, Clarke DT, Brownlow S, Jones GR (1997) Effect of temperature on the secondary structure of beta-lactoglobulin at $\mathrm{pH}$ 6.7, as determined by $\mathrm{CD}$ and IR spectroscopy: a test of the molten globule hypothesis. Biochem J 324:341-346

Sawyer L, Kontopidis G (2000) The core lipocalin, bovine beta-lactoglobulin. Biochim Biophys Acta Protein Struct Mol Enzymol 1482:136-148

Schmitt C, Bovay C, Vuilliomenet A-M, Rouvet M, Bovetto L, Barbar R, Sanchez C (2009) Multiscale characterization of individualized beta-lactoglobulin microgels formed upon heat treatment under narrow pH range conditions. Langmuir 25:7899-7909

Tavares GM, Croguennec T, Carvalho AF, Bouhallab S (2014) Milk proteins as encapsulation devices and delivery vehicles: applications and trends. Trends Food Sci Technol 37:5-20

Vasbinder AJ, Alting AC, Visschers RW, de Kruif CG (2003) Texture of acid milk gels: formation of disulfide cross-links during acidification. Int Dairy J 13:29-38

Vasbinder AJ, van de Velde F, de Kruif CG (2004) Gelation of casein-whey protein mixtures. J Dairy Sci 87: 1167-1176

Yan Y, Seeman D, Zheng B, Kizilay E, Xu Y, Dubin PL (2013) pH-dependent aggregation and disaggregation of native beta-lactoglobulin in low salt. Langmuir 29:4584 4593

Yong Y, Foegeding E (2010) Caseins: utilizing molecular chaperone properties to control protein aggregation in foods. J Agric Food Chem 58:685-693

Zhou P, Liu X, Labuza TP (2008) Moisture-induced aggregation of whey proteins in a protein/buffer model system. J Agric Food Chem 56:2048-2054 